\title{
Cytotoxicity Problem Identified
}

National Cancer Institute

\section{Source}

National Cancer Institute. Cytotoxicity Problem Identified. NCI Thesaurus. Code C139483.

The device was found to have an undesirable level of toxicity to living cells. 